DOI: $10.19195 / 2084-5065.46 .7$

\title{
Modyfikacja kary w postępowaniu wykonawczym
}

\author{
GRZEGORZ WICIŃSKI \\ Zakład Prawa Karnego Wykonawczego \\ Katedra Prawa Karnego Międzynarodowego \\ Wydział Prawa i Administracji Uniwersytetu Łódzkiego
}

1. Skupiając się na genezie oraz aksjologicznych motywach torujących drogę postępowym ideom w dziedzinie wykonania kary, a w tym rzędzie przede wszystkim - kary pozbawienia wolności, wypada przypomnieć pogląd C. Beccarii na temat celu kary. Ten niekwestionowany prekursor nauki o karze głosił, że

celem kary nie jest ani torturowanie i męczenie wrażliwej istoty, ani też uczynienie nie istniejącym przestępstwa, które zostało już popełnione [...]. Cel kary sprowadza się więc do tego, aby przeszkodzić winnemu w wyrządzeniu nowych szkód obywatelom oraz aby powstrzymać innych od wyrządzenia szkód tego samego rodzaju ${ }^{1}$.

Dążenie do rozwinięcia prezentowanego poglądu skupiało uwagę innych przedstawicieli postępowych nurtów XVIII-wiecznej Europy. Tematyka wypowiedzi skłania do przywołania zasadniczych wniosków wynikających z pracy J. Howarda, uznanego za pierwszego „międzynarodowego inspektora więziennictwa"2. Po pierwsze, podważał on stosowanie kary odbierającej skazanemu nadzieję powrotu do społeczeństwa, po drugie zaś - głosił konieczność zwalniania przed terminem więźniów

${ }^{1}$ C. Beccaria, O przestęstwach i karach, Warszawa 1959, s. 88.

2 J. Howard, The State of the Prisons in England and Wales, London 1777; J. Howard, Historical Remarks and Anecdotes on the Castle of Bastille, London 1784.

Nowa Kodyfikacja Prawa Karnego 46, 2017

(C) for this edition by CNS 
pracowitych i wykazujących poprawę. Nie ulega więc wątpliwości, że w prezentowanym otoczeniu aksjologicznym i na gruncie późniejszych koncepcji pozytywistycznych jedynie w programie progresywnego systemu wykonywania kary pozbawienia wolności można było wdrażać głoszone wartości.

System progresywny wykonywania kary pozbawienia wolności już w swym pierwotnym kształcie opracowanym przez A. Maconochiego ${ }^{3}$ czy W. Croftona, który wprowadzając do tzw. systemu irlandzkiego instytucję ,więzienia przejściowego", zakładał potrzebę złagodzenia ,przejścia” z warunków izolacji penitencjarnej do życia na wolności ${ }^{4}$, w sposób wręcz nierozerwalny związany był z potrzebą — jak dziś mówimy - modyfikacji kary w postępowaniu wykonawczym. A. Maconochie uznawał, że

przymus wobec skazanego jest bezcelowy, więźnia należy nauczyć dokonywania wyborów między dobrem a złem, aby los oddać w jego własne ręce, aby własnym wysiłkiem dążył do poprawy warunków w więzieniu i przyczyniał się do skrócenia terminu orzeczonej przez sąd kary5.

Jedynie motywowanie sprawcy do przyzwoitego zachowania może pobudzić u niego „odruch” praktykowania umiarkowanych zachowań. Warto zaznaczyć, iż doniosłość ostatniej z podniesionych uwag doceniał już Arystoteles, uznając, że ,stajemy się cnotliwi praktykując przyzwoite zachowanie, które kształtuje się poprzez powtarzanie dobrych uczynków". Wyraźnie pojawia się przy tym podejściu aspekt behawioralny, jakże bliski współczesnej doktrynie polityczno-kryminalnej propagowanej zwłaszcza w Stanach Zjednoczonych Ameryki Północnej.

Równoległe funkcjonowanie na przełomie XIX i XX w. systemu celkowego - gloryfikującego koncepcję prawa karnego czynu — dla którego aksjologiczne motywy zbudowali przedstawiciele szkoły klasycznej prawa karnego, nie dość, że nie tworzyło programu wykonywania kary pozbawienia wolności w schemacie prospektywnym ${ }^{6}$, to $\mathrm{w}$ jego następ-

3 A. Maconochie, Thoughts on Convicts Management, London 1839; A. Maconochie, Crime and Punishment, London 1846.

4 Zob. S. Pławski, Prawo penitencjarne, Warszawa 1968, s. 80-81.

5 Zob. S. Walczak, Prawo penitencjarne. Zarys systemu, Warszawa 1972, s. 114.

6 J. Waszczyński, Prawo karne w zarysie. Nauka o karze i innych środkach penalnych, Łódź 1983, s. 14-15.

Nowa Kodyfikacja Prawa Karnego 46, 2017

(C) for this edition by CNS 
stwie bardzo często dochodziło nawet do całkowitego rozkładu konstrukcji psychicznej sprawcy. Było bowiem jedynie kwestią czasu determinowanego właściwościami osobistymi więźnia — zwykle krótkiego — gdy dysproporcja pomiędzy czasem a przestrzenią prowadziła do zaburzeń, a nawet chorób psychicznych, nie wyłączając stanów najcięższych, takich jak choćby stupor. Odizolowanie więźnia przebywającego w małej celi od społeczności — choćby więziennej — buduje dla istoty ludzkiej klimat opresji wręcz trudnej do wyobrażenia.

Pomimo postępowych haseł wieńczących obrady I Kongresu Penitencjarnego we Frankfurcie nad Menem (1846 r.) idea tzw. ,sprawiedliwego odwetu za popełniony zły czyn sprawcy” niosąca z sobą dogmat ,kary surowej" — jak się w praktyce okazało — była dysfunkcjonalna. Nie mogła przeto realizować wychowawczego celu kary pozbawienia wolności, a co gorsza - była zaprzeczeniem wykonywania jej w sposób zindywidualizowany czy humanitarny, z poszanowaniem godności sprawcy.

Retrospektywna koncepcja kary, która, nawiasem mówiąc, kwestionowana była również np. przez Senekę, w bardzo skromnym (wręcz niezbędnym) zakresie objawia potrzebę jej modyfikacji w stadium wykonawczym, sprowadzając rzecz całą do takiej zmiany treści kary, która w niezbędnym zakresie jedynie łagodziła opresję, jakiej poddany był sprawca.

Ewolucja prawa karnego od czasów C. Beccarii, J. Howarda czy J. Benthama ${ }^{7}$, tj. od końca XVIII w., prowadziła stopniowo do wykształcenia się koncepcji kary celowej — zorientowanej na dążenie do osiągnięcia celu wychowawczego, którego finalnym objawem winna być readaptacja społeczna sprawcy ${ }^{8}$. Zwieńczenie tych wartości budował twórczy dorobek pozytywistów, w tym rzędzie zwłaszcza przedstawicieli szkoły socjologicznej prawa karnego, którzy, przede wszystkim w osobach F. Liszta, É. Durkheima, a w Polsce prof. J. Makarewicza czy prof. B. Wróblewskiego, wprowadzili do prawa karnego na szeroką skalę zasady polityki typologiczno-kryminalnej, a w ślad za tym koncepcję prawa karnego sprawcy ${ }^{9}$.

7 J. Bentham, Panopticon, or the Inspection House, London 1791.

8 Koncepcję tzw. kary celowej, zorientowanej na potrzebę odpłaty za popełniony czyn, wypada postrzegać w kategoriach karykaturalnej formy racjonalizacji kary.

9 E.S. Rappaport, Polityka kryminalna w zarysie, Łódź 1946, s. 90 n.

Nowa Kodyfikacja Prawa Karnego 46, 2017

(C) for this edition by CNS 
Przedstawiciele szkoły socjologicznej przyczyny przestępczości wiązali z oddziaływaniem na sprawcę czynników społecznych, uwzględniając jednocześnie wpływ cech psychofizycznych oddziałujących na procesy decyzyjne niosące z sobą potencjał czynów inkryminowanych.

Jeśli zaś chodzi o zasadę indywidualizacji wymiaru i wykonania kary, zakreśla ona w takim otoczeniu aksjologicznym, rzecz jasna, optykę prospektywną, zorientowaną na readaptację społeczną sprawcy oraz w ściśle oznaczonym zakresie stosowanie łącznie z karą, lub zamiast niej, środków zabezpieczających, które - nawiasem mówiąc - otworzyły w Europie drogę dla tzw. kodeksów dwutorowych.

Kodeks karny z 1932 r. ${ }^{10}$, którego twórcą w głównej mierze był prof. J. Makarewicz, mocą art. 84 przewidywał stosowanie takich środków w formie obligatoryjnej - chodzi tu o zakład dla sprawców niepoprawnych, zawodowych z nawyknienia, recydywistów — oraz na podstawie art. 83 — fakultatywnie dla sprawców wykazujących ,wstręt do pracy”, których można było kierować do tzw. domów pracy przymusowej na czas do 5 lat.

Przechodząc do stanu obecnego, wypada zauważyć, że system zarówno prawa karnego, jak i prawa wykonywania kar i innych środków penalnych w Polsce wprost opiera się w swym głównym nurcie na regulacjach normatywnych. Jest to zabieg konieczny z tego względu, że ta oczywista prawda bez jakiejkolwiek refleksji bywa pomijana przez zwolenników retrybutywnych (odwetowych) koncepcji neoklasycznych — już to nawet nie tyle kary, ile w ogóle prawa karnego - forsujących swoje poglądy w oderwaniu od litery prawa, a w ślad za tym i aksjologicznych podstaw stanowiących fundament całego obowiązującego systemu prawa karnego. Twierdzenie, że prawo karne rzekomo „,przewiduje nacechowaną potępieniem, o d w e t o w ą [podkr. - GW] reakcję na wyrządzone bezprawie", jest tego przykładem ${ }^{11}$. Podobne zjawisko - jednak nie na tak szeroką skalę - można było obserwować także w dobie II RP i to rychło po wejściu w życie kodeksu karnego z 1932 r. ${ }^{12}$

10 Rozporządzenie Prezydenta RP z dnia 11 lipca 1932 r. (Dz.U., Nr 60, poz. 571 ze $\mathrm{zm}$.).

11 Zob. np. E. Hryniewicz-Lach, Kompensacja szkód i krzywd w prawie karnym, „Prokuratura i Prawo” 2016, nr 3, s. 82.

12 G. Wiciński, Postępowania incydentalne zwiąane z wykonaniem kary pozbawienia wolności w programie probacji, Łódź 2012, s. 36-40.

Nowa Kodyfikacja Prawa Karnego 46, 2017

(C) for this edition by CNS 
Jeżeli współcześnie mówimy o modyfikacji kary w postępowaniu wykonawczym, to genezy takiego modelu jej egzekucji należy poszukiwać na gruncie kierunków pozytywistycznych, a zwłaszcza w sferze doktryny szkoły socjologicznej prawa karnego, idąc zaś dalej — progresywnego modelu wykonywania kary pozbawienia wolności, którego najistotniejszym elementem była i jest instytucja warunkowego zwolnienia.

Trzeba wyraźnie zauważyć, że współczesny system wykonywania kary pozbawienia wolności w Polsce jest określany jako system wolnej progresji. W ujęciu modelowym sytuacja skazanego jest przy takim podejściu uzależniona - w granicach prawem przewidzianych — od postępów (albo braku postępów) w procesie readaptacji społecznej.

Systematyka typów, rodzajów zakładów karnych oraz systemów wykonywania kary pozbawienia wolności zakreśla w stopniu decydującym prawne formy indywidualizacji wykonywania kary pozbawienia wolności w schemacie systemu progresywnego wyznaczającego w swej istocie treść kary, na którą składają się uprawnienia przysługujące i obowiązki spoczywające na sprawcy w czasie izolacji penitencjarnej, która w założeniu powinna prowadzić do osiągnięcia społecznie akceptowanego jej celu. Zgodnie z art. 67 k.k.w. ${ }^{13}$ jest nim readaptacja społeczna osadzonego, rozumiana w kategoriach wzbudzania woli współdziałania w kształtowaniu społecznie akceptowanych postaw, poczucia odpowiedzialności oraz potrzeby przestrzegania porządku prawnego, i tym samym powstrzymywanie się przez niego od powrotu do przestępstwa.

2. Z uwagi na to, że każdy rodzaj kary czy innej formy reakcji na przestępstwo de lege lata zakłada w pierwszym rzędzie realizację wychowawczego i zapobiegawczego celu (np. art. 53 § 1 k.k., art. 56 i 59 k.k., art. $53 \S 1$ k.k.w., art. 67 § 1 k.k.w., art. 1 ust. 3 pkt $4-5$ UoSW $^{14}$ ), zasada modyfikacji obejmuje nie tylko karę pozbawienia wolności, lecz także postępowania w sprawie wykonywania innych kar i środków penalnych, w tym zwłaszcza środków związanych z poddaniem sprawcy próbie (tzw. środków probacyjnych).

13 Ustawa z dnia 6 czerwca 1997 r. Kodeks karny (Dz.U., Nr 90, poz. 557 ze zm.).

14 Ustawa z dnia 26 kwietnia 1996 r. o Służbie Więziennej (Dz.U. 2002, Nr 207, poz. 1761 t.j. ze zm.) (dalej jako: UoSW).

Nowa Kodyfikacja Prawa Karnego 46, 2017

(C) for this edition by CNS 
Godzi się odnotować, że z punktu widzenia zasad prawa karnego wykonawczego zasada modyfikacji kary jest podejściem adekwatnym w sytuacji głębokiego respektu wobec zasady humanitaryzmu i poszanowania godności człowieka (art. 4 k.k.w., art. 30 Konstytucji RP obejmujący — w granicach godności człowieka — prawo do nadziei) oraz zasady indywidualizacji wykonania kary (art. 67 k.k.w., art. $76 \S 8$ k.k.w., art. 82 $\S 1$ k.k.w.), a w ślad za nią zasady resocjalizacji (art. $76 \S 1$ pkt 4 k.k.w., art. 1 ust. 3 pkt 1 UoSW).

Wypada w tym miejscu wyraźnie podkreślić, że wyłącznie na gruncie zakreślonych przez ustawodawcę w taki sposób założeń systemowych otwiera się realna możliwość powodzenia w dążeniu do realizacji wskazanych wcześniej celów wykonania kary lub innego środka penalnego.

Trzeba zauważyć, że, jak pokazują dane statystyczne, zagadnienie modyfikacji kary ogniskuje się obecnie w głównej mierze wokół instytucji autonomicznych oraz incydentalnych związanych z wykonywaniem kary pozbawienia wolności bez warunkowego zawieszenia jej wykonywania ${ }^{15}$.

Odnotujmy, że z perspektywy politycznokryminalnej jest to schemat zasługujący na ograniczoną akceptację, biorąc pod uwagę potrzebę jego szerokiej realizacji również w odniesieniu do pozostałych kar i środków penalnych. Opracowany w prawidłowy sposób i konsekwentnie wdrażany program oddziaływania na sprawców drobniejszych przestępstw skazanych na kary wolnościowe lub inne środki penalne daje solidne

15 Z danych Wydziału Statystyki Ministerstwa Sprawiedliwości wynika, że w minionej dekadzie sądy orzekały kary pozbawienia wolności z warunkowym zawieszeniem jej wykonania średnio w ponad $60 \%$ spraw, w tym w ponad $70 \%$ było to tzw. proste zawieszenie, tj. bez orzeczenia dozoru kuratora oraz obowiązków okresu próby. W około $20 \%$ orzeczono kary grzywny, a niewiele ponad $10 \%$ to skazania na kary ograniczenia wolności. W obecnej dekadzie można zaobserwować niewielką korektę polityki karnej w tym zakresie. Dane Wydziału Statystycznej Informacji Zarządczej Ministerstwa Sprawiedliwości pokazują spadek udziału kar warunkowo zawieszonych do 55\% w roku 2013 oraz wzrost orzekanych kar ograniczenia wolności do 12,4\% w roku 2012 — niestety w kolejnych latach (2013-2015) ten udział w strukturze wszystkich orzekanych kar ponownie obniżył się do poziomu ok. 11\%. Zob. także: A. Nawój-Śleszyński, Przeludnienie więzień w Polsce - przyczyny, następstwa i możliwości przeciwdziałania, Łódź 2013, s. 274, 280-281.

Nowa Kodyfikacja Prawa Karnego 46, 2017

(C) for this edition by CNS 
podstawy do zapobieżenia późniejszym — zwykle już poważniejszym naruszeniom prawa.

Niemniej, trzeba się zgodzić, że na ogół, albo w ujęciu modelowym, skazani na tzw. bezwzględną karę pozbawienia wolności są zwykle sprawcami cięższych przestępstw; stąd też niekwestionowana potrzeba readaptacji społecznej, a w ślad za nią zabezpieczenie społeczeństwa przed ryzykiem popełnienia kolejnego przestępstwa są sprawą szczególnie ważną. Nadto, nie ulega wątpliwości, że z wykonywaniem kary izolacyjnej — ipso fatum opresyjnej w stopniu najwyższym — musi się wiązać skomplikowany i precyzyjnie oznaczony proces jej egzekucji, również z punktu widzenia potrzeby niedopuszczenia do naruszeń praw osadzonego, gwarantowanych — jak wiadomo — nie tylko w kodeksie karnym wykonawczym lub innych ustawach, lecz również w Konstytucji RP oraz w szeregu aktów prawa międzynarodowego ratyfikowanych przez Polskę ${ }^{16}$.

Oba przedstawione argumenty torują aksjologiczne motywy porządku normatywnego w obszarze prawa karnego wykonawczego, który zakotwiczony jest $\mathrm{w}$ modelu nieskończonej liczby postępowań incydentalnych i autonomicznych.

Pomijając przypadki sprawców najcięższych przestępstw (zabójstw, zgwałceń, rozbojów itd.) — z punktu widzenia założeń polityki kryminalnej - doniosłą rolę w kwestii modyfikacji kary trzeba przypisywać nienależycie docenianej w praktyce problematyce orzekania, a zwłaszcza wykonywania środków związanych z poddaniem sprawcy próbie oraz egzekucji kar wolnościowych.

Bardziej zdecydowane - niż ma to obecnie miejsce - sięgnięcie przez sądy i inne organy postępowania wykonawczego po wiedzę osadzoną w paradygmacie standardu dogmatycznego opartego na fundamencie prognozowania kryminologicznego na gruncie orzekania, a zwłaszcza wykonywania środków probacyjnych, najpewniej zmieniłoby niespotykany w innych krajach obraz empiryczny, gdzie - statystycznie rzecz biorąc - większość osadzonych w polskich zakładach karnych rekrutuje

16 Zob. zwł. art. $67 \S 3$, art. 101-115a k.k.w. oraz art. 31.3, art. 40, art. 41.2 i 5 , art. 45, art. 53 Konstytucji RP. Zob. także: A. Płonka, Prawa więźnia, [w:] Prawa człowieka. Wybrane zagadnienia i problemy, red. L. Koba, W. Wacławczyk, Warszawa 2009, s. $384-520$.

Nowa Kodyfikacja Prawa Karnego 46, 2017

(C) for this edition by CNS 
się spośród osób, którym nie udało się pomyślnie przejść okresu próby. Dodajmy dla porządku — w dominującej większości w związku z warunkowym zawieszeniem wykonania kary pozbawienia wolności. Nieco lepiej przedstawia się sytuacja osób warunkowo zwolnionych z reszty kary pozbawienia wolności ${ }^{17}$.

2a. Wspomniano wcześniej, że efektywne oddziaływanie na treść, a nawet rodzaj reakcji karnej odbywa się na drodze określonych procedur albo - mówiąc inaczej — postępowań autonomicznych i incydentalnych. Przyjmuję, że jest to najważniejszy z paradygmatów, na którym opiera się zasada modyfikacji kary w postępowaniu wykonawczym.

Mówiąc o postępowaniach autonomicznych, mam na uwadze składowe kształtujące treść lub formę kary (środka penalnego). Innymi słowy - postępowania autonomiczne są immanentną składową egzekucji danej kary (środka penalnego). Wynika z tego, że każdemu skazanemu odbywającemu karę (środek penalny) w ramach odpowiedniego - przewidzianego w prawie karnym wykonawczym - programu systemowo przysługuje dostęp do postępowań autonomicznych.

Jeśli spojrzeć na karę pozbawienia wolności, do najważniejszych postępowań autonomicznych bezspornie należą postępowania w sprawie warunkowego przedterminowego zwolnienia (art. 77 n. k.k.). Każdemu bowiem skazanemu ustawodawca przyznał prawo do ubiegania się o zastosowanie wobec niego tej instytucji. Prawo to należy wyprowadzać również (albo przede wszystkim) w oparciu o art. 30 Konstytucji RP stanowiący o przyrodzonej i niezbywalnej godności każdego człowieka — rozumianej w tym przypadku jako możliwość zmiany relacji ze środowiskiem ludzi przestrzegających społecznie akceptowanych wartości.

W podobnej optyce sytuują się postępowania otwierające programy środków oddziaływania wychowawczego (praca, nauka, zajęcia kulturalno-oświatowe, sportowe, kontakty ze światem zewnętrznym, środki terapeutyczne), które w świetle art. $67 \S 3$ k.k.w. stanowią podstawowe formy zindywidualizowanego oddziaływania na osoby osadzone w zakładach karnych określonego rodzaju, typu oraz systemu wykonywania kary pozbawienia wolności.

17 Szerzej na ten temat: G. Wiciński, op. cit., s. 458-474.

Nowa Kodyfikacja Prawa Karnego 46, 2017

(C) for this edition by CNS 
Podobnie — dla przykładu — na zasadach określonych w art. 83 k.k. skazany na karę ograniczenia wolności może zostać zwolniony z reszty tej kary bądź, jeżeli względy wychowawcze za tym przemawiają, w okresie wykonywania kary ograniczenia wolności sąd może w szczególności ustanawiać, zmieniać obowiązki, o których mowa w art. 72 k.k., zmniejszyć liczbę godzin wykonywania pracy w stosunku miesięcznym (art. 61 k.k.w.), a nawet zmienić formę kary, tj. obowiązek wykonywania nieodpłatnej kontrolowanej pracy na cele społeczne, na potrącenie $\mathrm{z}$ wynagrodzenia według zasad ustanowionych w art. 63a k.k.w. ${ }^{18}$ Dalsze przykłady można mnożyć.

W odniesieniu do kary grzywny o postępowaniu autonomicznym można mówić zwłaszcza w przypadku ubiegania się sprawcy o rozłożenie jej na raty w reżimie art. 49 k.k.w.

Jeśli chodzi z kolei o postępowania incydentalne, charakteryzują się one tym, że są następstwem okoliczności, o których sąd czy inny organ postępowania wykonawczego nie wiedział w chwili orzekania albo w chwili rozpoczęcia wykonywania kary (środka penalnego). „Incydentalne" to nic innego jak zdarzenie, które jest przypadkowe, niespodziewane, nieoczekiwane. W szeregu tych postępowań w pierwszym rzędzie sytuują się: umorzenie, zawieszenie postępowania wykonawczego (art. 15 $\S 1$ i 2 k.k.w.), zmiana lub uchylenie postanowienia w trybie art. 24 k.k.w. oraz - rzecz jasna - odroczenie (art. 62 i 150 n. k.k.w.) i przerwa wykonania kary (art. 63 i 153 n. k.k.w.) — zarówno ograniczenia, jak i pozbawienia wolności.

Nie da się na ogół przewidzieć, że skazany np. umrze, zapadnie na ciężką, przewlekłą chorobę, a nawet opuści zakład karny bez zezwolenia i nie da się go ująć albo że stan jego zdrowia uniemożliwi wykonywanie kary lub dopadnie go choroba psychiczna. Podane okoliczności są tylko przykładem przesłanek otwierających drogę do wszczęcia przez właściwy sąd podanych postępowań incydentalnych.

Warto w tym miejscu podnieść zarzut, że z niejasnych powodów ustawodawca mocą nowelizacji kodeksu karnego wykonawczego przeprowadzonej w $2011 \mathrm{r} .{ }^{19}$ ograniczył zakres postępowań incydentalnych

18 Zob. również art. 63b $\S 1$ k.k.w.

19 Dz.U., Nr 240, poz. 1431.

Nowa Kodyfikacja Prawa Karnego 46, 2017

(C) for this edition by CNS 
związanych z wykonaniem kary grzywny - eliminując z porządku prawnego możliwość odroczenia ściągnięcia tej kary (d. art. 49 k.k.w.). Nie sposób wykluczyć sytuacji, gdy skazany za miesiąc czy pół roku może spodziewać się np. wypłaty dywidendy albo innego świadczenia, a środki uzyskane w tej formie mogą zapewnić możliwość uiszczenia grzywny bez uszczerbku dla osób najbliższych (zasada niepodzielności kary).

Istnieje, co prawda, wspomniana wcześniej ewentualność rozłożenia grzywny na raty, jednak uważam, że nie rozwiązuje ona w pełni zakreślonego podanym przykładem zagadnienia, a nadto, w dążeniu do efektywnego wykonania orzeczonej przez sąd kary wolnościowej, czego nie można kwestionować — a taką jest przecież kara grzywny — w żadnym razie nie należy ograniczać w postępowaniu wykonawczym form oddziaływania lub modyfikacji prowadzących do osiągnięcia założonego celu. Wręcz przeciwnie — należy je poszerzać.

Kończąc, wypada dodać, że od strony czysto formalnej, tj. z punktu widzenia systematyki kodeksowej, postępowania, o których była mowa, zostały ujęte przede wszystkim w części szczególnej kodeksu karnego wykonawczego oraz aktach wykonawczych. Warto jednak również odnotować, że odnośne regulacje zostały przewidziane także i w części ogólnej — zarówno kodeksu karnego (np. art. 77 k.k.), jak i karnego wykonawczego (np. art. 15 i 24 k.k.w.).

Poważne wątpliwości pojawiają się w zakresie unormowań dotyczących warunkowego przedterminowego zwolnienia. Jako że mamy do czynienia z instytucją stricte penitencjarną, dlatego w najmniejszym stopniu nie przekonuje fakt usytuowania przepisów dotyczących przesłanek jej stosowania w części ogólnej kodeksu karnego (art. 77 n. k.k.).

2b. Wiadomym jest, że zarówno postępowania autonomiczne, jak i incydentalne mają zróżnicowany charakter. Przyjmuję w szczególności, że mogą prowadzić do modyfikacji (kary, środka penalnego) wewnętrznej albo zewnętrznej. W przypadku modyfikacji wew nętrznej mam na uwadze takie postępowania, które w stadium wykonawczym są zorientowane na modelowanie samej treści kary (środka penalnego) w kierunku prowadzącym optymalnie do osiągnięcia założonego celu (celów). 
Odwołując się do przykładów ilustrujących istotę omawianego podziału, należy wskazać możliwość zmiany przez właściwy organ postępowania wykonawczego w oznaczonych prawem granicach: typu, rodzaju zakładu karnego albo systemu wykonywania kary pozbawienia wolności i podążającą w ślad za tym wzajemną relację uprawnień i obowiązków osadzonego, która w sposób oczywisty oddziałuje na dolegliwość kary, a w konsekwencji stanowi podstawę systemu progresywnego. Można tu wskazać zwłaszcza na przykład dotyczący zakresu możliwych kontaktów ze światem zewnętrznym, np. w formie przepustek ${ }^{20}$.

Z kolei w programie probacji ów „mechanizm” motywowania sprawcy do ,praktykowania" prawidłowych, z punktu widzenia potrzeb w procesie readaptacji społecznej, postaw i zachowań jest w mojej ocenie najważniejszą jego częścią; już to z tego powodu, że sprawca przestępstwa na podstawie orzeczenia sądu przebywa w warunkach wolnościowych, a nie „na wolności", jak można słyszeć (niestety nie tylko w przekazie masowym).

Fakt ten determinuje potrzebę elastycznego reagowania przez sąd na postępy w readaptacji albo dające się uchwycić zagrożenia dla pomyślnego przebiegu okresu próby związanej zarówno $\mathrm{z}$ warunkowym umorzeniem postępowania karnego (art. 66 k.k.), jak i warunkowym zawieszeniem wykonania kary pozbawienia wolności (art. 69 k.k.) oraz warunkowym zwolnieniem (art. 77 k.k.). Stąd też w szczególności w okresie próby można oddać skazanego pod dozór (chyba że ten jest obligatoryjny), od dozoru zwolnić (art. 67 § 4 k.k., art. 74 § 2 in fine k.k., art. 159 § 1 k.k.w.) lub, jeżeli względy wychowawcze za tym przemawiają, można w okresie próby ustanawiać, rozszerzać lub zmieniać obowiązki wymienione w art. 72 $\S 1$ pkt 3-8 k.k. (art. $67 \S 4$ k.k., art. $74 \S 2$ k.k.) albo w art. $72 \S 1$ k.k., art. $72 \S 2$ k.k. (art. $159 \S 1$ k.k.w.).

W przypadku orzeczenia kary grzywny przykładem wewnętrznej modyfikacji w postępowaniu wykonawczym jest — rzecz jasna - możliwość rozłożenia jej przez sąd na raty (art. 49 k.k.w.).

20 Sumując maksymalny czas, na jaki można udzielać przepustek, otrzymamy liczbę przekraczającą 100 dni w roku. Zob. G. Wiciński, Instytucjonalne formy kontaktów ze światem zewnętrznym osób odbywających karę pozbawienia wolności, [w:] Aktualne problemy prawa karnego, kryminologii i penitencjarystyki. Ksiega ofiarowana Profesorowi Stefanowi Lelentalowi, red. K. Indecki, Łódź 2004, s. 506 n.

Nowa Kodyfikacja Prawa Karnego 46, 2017

(C) for this edition by CNS 
Zew nętrzna zaś modyfikacja kary (środka penalnego) w moim rozumieniu sprowadza się do zmiany już to wyłącznie mocą orzeczenia sądu — formy, rodzaju albo czasu trwania kary lub środka penalnego.

Zacznijmy od końca.

Jeśli chodzi o zmianę czasu trwania kary — rzecz jasna — możliwość tę prawo dopuszcza jedynie na korzyść sprawcy i pozostaje mieć nadzieję, że ów stan rzeczy nie ulegnie zmianie ${ }^{21}$; najbardziej oczywistym przykładem skrócenia czasu trwania kary jest możliwość zwolnienia z reszty kary ograniczenia wolności po odbyciu przynajmniej połowy tej kary i uznanie jej za wykonaną po spełnieniu - co oczywiste — odnośnych przesłanek materialnych, o których stanowi art. 83 k.k. Przepis tego artykułu wskazuje na potrzebę przestrzegania przez skazanego porządku prawnego, sumienne wykonywanie wskazanej pracy oraz obowiązków i środków karnych nałożonych (orzeczonych) na sprawcę.

Wcześniejsze, niż to wynika z orzeczenia sądu, uznanie kary ograniczenia wolności za wykonaną może nastąpić również w oparciu o art. 64 k.k.w. ${ }^{22} \mathrm{~W}$ sytuacji, gdy w okresie, na jaki karę orzeczono, nie został wykonany pełen wymiar pracy albo nie dokonano w całości potrąceń $\mathrm{z}$ wynagrodzenia za pracę lub też nie zostały wykonane inne nałożone przez sąd obowiązki, sąd orzeka, czy i w jakim zakresie uznać karę za wykonaną ze względu na osiągnięte cele wykonania tej kary, wynikające z art. $53 \S 1$ k.k.w. ${ }^{23}$

W podobnej logice systematyzuję regulacje kodeksowe dotyczące wykonania orzeczonych środków karnych (np. art. 84 § 1 i 3 k.k.) $)^{24}$.

21 Krytyczna ocena formuły — zbieżna ze stanowiskiem RPO — w jakiej ujęta została Ustawa z dnia 22 listopada 2013 r. o postępowaniu wobec osób z zaburzeniami psychicznymi stwarzającymi zagrożenie życia, zdrowia lub wolności seksualnej innych osób (Dz.U. 2014, 00, poz. 24), wyraźnie osłabia przedstawione oczekiwanie.

22 Inaczej niż w przypadku art. 83 k.k., który otwiera opisywaną możliwość po odbyciu przynajmniej połowy kary, art. 64 nie przewiduje w tym zakresie ograniczeń.

23 „Wykonanie kary ograniczenia wolności ma na celu wzbudzenie w skazanym woli kształtowania jego społecznie pożądanych postaw, w szczególności poczucia odpowiedzialności oraz potrzeby przestrzegania porządku prawnego".

$24 \mathrm{Z}$ zastrzeżeniem wyjątków wynikających z art. 84 § 2 k.k., zgodnie z art. $84 \S 1$ k.k.: „Sąd może po upływie połowy okresu, na który orzeczono środki karne wymienione w art. 39 pkt 1-3, uznać je za wykonane, jeżeli skazany przestrzegał porządku prawnego, a środek karny był w stosunku do niego wykonywany przynajmniej przez rok". Natomiast

Nowa Kodyfikacja Prawa Karnego 46, 2017

(c) for this edition by CNS 
Dalszym przykładem zewnętrznej modyfikacji kary jest możliwość umorzenia grzywny w części, a wyjątkowo - w całości, w wypadkach szczególnie uzasadnionych, gdy skazany z przyczyn od niego niezależnych nie może jej uiścić, a wykonanie tej kary w innej drodze okazało się niemożliwe lub niecelowe. Egzekucji nie zarządza się, jeżeli z okoliczności sprawy wynika, że byłaby ona bezskuteczna (art. $51 \S 1$ k.k.w.).

Szeroko zakrojoną problematykę wykonania kary zastępczej, już to w odniesieniu do kary grzywny, gdzie ustawodawca przewidział zamianę tej kary na pracę społecznie użyteczną (art. 45 n. k.k.w.) albo karę pozbawienia wolności (art. 46 k.k.w.), już to wobec kary ograniczenia wolności lub świadczenia pieniężnego albo nałożonych obowiązków (art. $65 \mathrm{n}$. k.k.w.), w obliczu uchylania się od stosownych powinności, kiedy to sąd zarządza wykonanie zastępczej kary pozbawienia wolności, traktuję jako przykłady zew nętrznej modyfikacji kary w postępowaniu wykonawczym, gdzie mamy do czynienia z oczywistą zmianą jej rodzaju.

Relatywnie najwięcej wątpliwości wzbudza problematyka dotycząca modyfikacji zewnętrznej w odniesieniu do środków związanych $\mathrm{z}$ poddaniem sprawcy próbie $\mathrm{i}$ to zarówno $\mathrm{w}$ odniesieniu do probation, jak i parole.

Jeszcze w latach 70. ubiegłego wieku przyjmowano traktować w szczególności warunkowe skazanie — jako modalność wykonania kary pozbawienia wolności ${ }^{25}$. Obecnie uznaje się, że mamy tu do czynienia z samodzielnymi środkami karnymi o walorach prewencyjno-wychowawczych, które należy traktować jako szczególną formę wymiaru albo wykonania kary pozbawienia wolności ${ }^{26}$.

Sumując więc - formą wykonania kary pozbawienia wolności może być jej warunkowe zawieszenie, warunkowe zwolnienie albo odbywanie

art. $84 \S 3$ k.k. stanowi, że: „Sąd może zwolnić skazanego z obowiązku orzeczonego na podstawie art. $41 \mathrm{~b} \S 5$ lub 7 [tj. obowiązek stawiennictwa w czasie trwania niektórych imprez masowych w jednostce Policji lub innym miejscu określonym przez komendanta Policji — GW] po upływie połowy okresu, na który go orzeczono, jeżeli obowiązek był stosowany przynajmniej przez rok, a zachowanie skazanego wskazuje, że dalsze stosowanie obowiązku nie jest niezbędne do spełnienia celów środka karnego".

25 M. Leonieni, Warunkowe zawieszenie wykonania kary, Warszawa 1974, s. 23; J. Śliwowski, Prawo i polityka penitencjarna, Toruń 1978, s. 183.

26 Zob. np.: A. Marek, Prawo karne, Warszawa 2000, s. 304; A. Zoll, [w:] Kodeks karny. Część ogólna, red. G. Bogdan et al., Kraków 2004, s. 1024.

Nowa Kodyfikacja Prawa Karnego 46, 2017

(C) for this edition by CNS 
w systemie dozoru elektronicznego (SDE). W tym ostatnim przypadku ustawodawca tytułując pierwotnie - w 2007 r. — ustawę wprost, stanowi, że jest ona „o wykonywaniu kary pozbawienia wolności poza zakładem karnym w systemie dozoru elektronicznego"27. Obecnie obowiązujący rozdział VIIa k.k.w. nie daje podstaw do zmiany stanowiska w tym zakresie.

Mówiąc o warunkowym zwolnieniu, trzeba przyjmować, że nie mamy do czynienia z instytucją powodującą skrócenie czasu, na jaki karę orzeczono, już to z tego powodu, że skazany w okresie próby nie przebywa „na wolności”. Obarczony dozorem kuratora, nałożonymi obowiązkami, nawet gdy nie został oddany pod dozór (art. 150 § 2 k.k.w.), albo przynajmniej ryzykiem kontroli przez sąd penitencjarny swoich poczynań w kontekście przestrzegania porządku prawnego w trybie art. $14 \S 1$ k.k.w., pozostaje w reżimie prawnym — różnym od tego, który obowiązuje ,zwykłe osoby" przebywające na wolności. Poza tym w przewidzianych prawem okolicznościach sąd penitencjarny może odwołać warunkowe zwolnienie. W podobnej optyce jawi się wykonywanie kary pozbawienia wolności w systemie stacjonarnego dozoru elektronicznego.

Spore zdziwienie mógł wywołać wyrok Trybunału Konstytucyjnego, który orzekając na tle d. art. $75 \S 1$ k.k. w zakresie, w jakim nie dopuszczano możliwości odstąpienia przez sąd od zarządzenia wykonania kary w sytuacji, gdy wobec skazanego ponownie orzeczono karę pozbawienia wolności z warunkowym zawieszeniem jej wykonania, przyjął co najmniej kontrowersyjny sposób patrzenia na rzeczony środek związany z poddaniem sprawcy próbie, stanowiąc, że ,w świetle znanych Trybunałowi uzasadnień wyroków sądów karnych, w praktyce orzeczniczej traktują one karę pozbawienia wolności z warunkowym zawieszeniem jej wykonania jako rodzaj kary [podkr. - GW] odmienny od bezwzględnej kary pozbawienia wolności"28. Nie wdając się - z oczywistych powodów — w głębszą polemikę, wystarczy zauważyć, że rodzaje kar w naszym prawie karnym zostały ujęte w art. 32 k.k., a jest to katalog zamknięty, w którym nie znajdujemy omawianego środka (kary?).

27 Ustawa z dnia 7 września 2007 r. (Dz.U., 2010 r., Nr 142, poz. 960 t.j. ze zm.).

28 Wyrok TK z 17 lipca 2013 r., sygn. akt SK 9/10, OTK 2013 r., nr 6, poz. 79, pkt 3.11 uzasadnienia. Zob. także zdanie odrębne sędziego TK, M. Granata, które w pełni podzielam.

Nowa Kodyfikacja Prawa Karnego 46, 2017

(C) for this edition by CNS 
Modyfikacja w omawianym zakresie może przebiegać w kierunku korzystnym dla sprawcy (warunkowe zwolnienie, SDE — zarówno w formie front door, jak i back door, art. 152 i 155 k.k.w.) albo przeciwnie, tj. podjęcie postępowania karnego (art. 68 k.k.), zarządzenie [podkr. — GW w nawiązaniu do akapitu poprzedzającego] wykonania kary pozbawienia wolności (art. 75 k.k.), odwołanie warunkowego zwolnienia (art. 160 k.k.w.), uchylenie zezwolenia na wykonywanie kary pozbawienia wolności w SDE (art. 43 zae k.k.w.). Jednak nawet w przypadku niekorzystnej dla sprawcy decyzji sądu w przedmiocie modyfikacji na ogół nie zamyka się sprawcy drogi w dążeniu do ponownego orzeczenia zmierzającego do zewnętrznej modyfikacji kary pozbawienia wolności (np. art. 81 k.k. albo 152 k.k.w.), chyba że mamy do czynienia z uchyleniem zezwolenia na odbycie kary w systemie dozoru elektronicznego — ponowne udzielenie takiego zezwolenia w tej samej sprawie jest bowiem niedopuszczalne (art. 43 zae k.k.w.).

2c. Uwzględniając zróżnicowane obszary podsystemów normatywnych, tj. przepisy prawa karnego, karnego procesowego, wykonawczego oraz wydane na ich podstawie akty wykonawcze, w tym rzędzie dotyczące w szczególności porządku normatywnego związanego z wykonywaniem kary pozbawienia wolności, wypada, jak się zdaje, postępować refleksyjnie, to znaczy skupić się na motywach, którymi prawodawca się kierował, porządkując warstwę normatywną modyfikacji kary w stadium wykonawczym. Podążając za przyjętym założeniem, zwrócę uwagę na kolejne formy modyfikacji, które mają charakter trwały albo epizodyczny. Zastrzec przy tym należy, że w pierwszym wypadku można mówić o modyfikacji warunkowej (względnej) albo bezwarunkowej (bezwzględnej).

Argumentem przemawiającym za trwałością danego postępowania jest przyjęte przez ustawodawcę założenie, że sprawca, wobec którego podjęto odnośne postępowanie, powinien w świetle przyjętych założeń prawnych zrealizować założony cel, natomiast to, czy tak się stanie, $\mathrm{w}$ istocie rzeczy zależy już od niego.

W zestawieniu trwałych form modyfikacji warunkowej sytuują się w pierwszym rzędzie instytucje budujące program probacji, ze szczególnym uwzględnieniem warunkowego zawieszenia wykonania 
kary pozbawienia wolności (art. 69 n. k.k., art. 152 k.k.w.), względnie warunkowego zwolnienia - orzekanego już to na zasadach ogólnych (art. 77 n. k.k.), już to np. w trybie art. 155 k.k.w. (po okresie rocznej przerwy, a odbyciu 6 miesięcy kary do 3 lat pozbawienia wolności).

Warto zauważyć, że w przypadku niepomyślnego przebiegu okresu próby, w związku z karą pozbawienia wolności z warunkowym zawieszeniem jej wykonania, oprócz warunkowego zwolnienia podobnie trwały i również w zględny charakter wykazuje możliwość ponownego zastosowania wobec sprawcy warunkowego zawieszenia wykonania kary - w programie art. 152 k.k.w. (warunkowe zawieszenie wykonania kary orzeczonej do 1 roku, po okresie rocznego odroczenia udzielonego w oparciu o art. 150 n. k.k.).

Inną instytucją, której nie da się pominąć, z tej racji, że jest specyficznym dla prawa karnego wykonawczego rozwiązaniem względnie trwałej formy modyfikacji kary w postępowaniu wykonawczym, jest możliwość zmiany lub uchylenia wydanego postanowienia w trybie art. 24 k.k.w., tj. jeżeli ujawnią się nowe lub poprzednio nieznane okoliczności istotne dla rozstrzygnięcia. Jednak w zależności od przedmiotu, którego może dotyczyć orzeczenie wydane przez sąd w tym trybie, nie sposób jest określić in abstracto, z jaką konkretnie formą modyfikacji można mieć do czynienia.

W zgoła odmiennej optyce sytuuje się bezwar unkowa forma trwałej modyfikacji. Typowym przykładem takich rozwiązań normatywnych są regulacje dotyczące np. ułaskawienia (art. 560 n. k.p.k.), umorzenia postępowania wykonawczego (art. $15 \S 1$ k.k.w.), umorzenia kary grzywny — w części albo w całości (art. $51 \S 1$ k.k.w.) bądź to zwolnienia z reszty kary ograniczenia wolności (art. 83 k.k.) albo uznanie tej kary za wykonaną w trybie art. 64 k.k.w., jeżeli jej cele zostały osiągnięte wcześniej, niż to orzekł sąd w wyroku.

Jeśli chodzi o epizodyczną modyfikację kary, następuje ona przy założeniu, że sprawca powróci do programu wykonywania orzeczonej kary przede wszystkim po zakończeniu okresu odroczenia jej wykonania — tak w odniesieniu do kary ograniczenia wolności (art. 62 k.k.w.), jak pozbawienia wolności (art. 150 n. k.k.w.), przerwy wykonania kary odpowiednio art. 63 i 153 k.k.w. Zastrzec tu należy, że jeśli chodzi o karę pozbawienia wolności w pewnych wypadkach, o których była mowa, 
ustawodawca otworzył możliwość jej wykonywania w innej formie (np. art. 152 i 155 k.k.w.). Podobne wyjątki w zasadzie nie dotyczą zawieszenia postępowania wykonawczego w oparciu o art. $15 \S 2$ k.k.w., choć nie można wykluczyć w tym wypadku możliwości wystąpienia modyfikacji bezwzględnej (trwałej) w oparciu o art. 15 § 1 k.k.w. stanowiący podstawę do umorzenia postępowania wykonawczego.

W tej części, gdy modyfikacja określana mianem epizodycznej dotyczy kary pozbawienia wolności, podniesiony wcześniej jej instytucjonalny związek z odpowiednimi formami modyfikacji warunkowej względnej dotyczy postępowań incydentalnych otwierających drogę ku probacji, wskazanych zwłaszcza w art. 152 i 155 k.k.w.

Podane przykłady wzajemnego przenikania form modyfikacji kary w postępowaniu wykonawczym stanowią jedynie ilustrację występowania możliwych zależności. W praktyce może to być sygnałem inspirującym do dalszych, pogłębionych badań prowadzonych w obszarze dogmatyki prawa karnego wykonawczego w kierunku poszukiwania innych — nowych lub koherentnych — zależności występujących także w innych obszarach, o których w części była już mowa, wykazując tym samym bardziej, niż to przyjęto postrzegać, złożony w aspekcie dogmatycznym charakter omawianej dziedziny prawa karnego.

3. Tematyka zakreślona $\mathrm{w}$ tytule niewątpliwie otwiera również pole do rozważań prowadzonych na innych płaszczyznach. Jedną z nich jest kwestia dostępu do określonego programu modyfikacji w wybranych kategoriach sprawców przestępstw. Odnośne ograniczenia mogą w tym względzie mieć charakter prawny lub faktyczny.

Szczególnym przykładem modyfikacji sankcji karnej, której zakres został zakwestionowany mocą wspomnianego wcześniej wyroku TK, jest d. art. $75 \S 1$ k.k. dotyczący obligatoryjnego zarządzenia wykonania kary warunkowo zawieszonej (w zw. z art. 45.1 Konstytucji). Nie wnikając, z oczywistych względów, w merytoryczne aspekty rozstrzygnięcia, z systemowej perspektywy pod znakiem zapytania TK postawił de facto inne zapisy kodeksu karnego wykonawczego przewidujące wydanie przez sąd postanowienia $\mathrm{w}$ formie obligatoryjnej albo ex lege.

Można jedynie zauważyć, że skutkiem rzeczonego wyroku oraz aktualnej wersji art. $75 \S 2$ a k.k.w. albo art. $160 \S 4$ k.k.w. jest poszerzenie 
władzy dyskrecjonalnej sądów w zakresie modyfikacji kary (środków penalnych) z jednej strony, z drugiej zaś - ograniczenie tzw. pewności prawa w obliczu podniesienia w prawie karnym wykonawczym rangi tzw. klauzul generalnych. Na gruncie potrzeby dążenia w prawie karnym do możliwie ,pewnych” regulacji normatywnych w obszarze polityki legislacyjnej omawiana tendencja budzi poważne wątpliwości.

Przechodząc do zagadnień mniej kontrowersyjnych, prawnym ograniczeniem w dostępie do modyfikacji zewnętrznej są zwłaszcza formalne przesłanki zwolnienia z reszty kary ograniczenia wolności (art. 83 k.k.) oraz warunkowego zwolnienia z reszty kary pozbawienia wolności (zwłaszcza wymóg odbycia $3 / 4$ kary przez recydywistów wielokrotnych art. $78 \S 2$ k.k.). Krokiem w dobrym kierunku było zniesienie w 2010 r. tzw. minimum absolutnego, tj. odbycia przez osadzonego 6 miesięcy kary $^{29}$.

Ustawodawca formułując przesłanki formalne stosowania instytucji prawa karnego wykonawczego, ma na uwadze przede wszystkim walory o charakterze ogólnoprewencyjnym — niemniej pojawia się w takiej sytuacji realne ryzyko osłabienia in concreto zasady resocjalizacji oraz wychowawczego celu kary. Rzecz w tym, że — przyjmując hipotetycznie — nawet gdy szczególnoprewencyjny cel kary został wcześniej osiągnięty, sprawca będzie musiał np. przebywać w zakładzie karnym do czasu odbycia choćby połowy orzeczonej przez sąd kary. Jednocześnie już sam system wolnej progresji stwarza określone ograniczenia w dostępie do kolejnych etapów odnośnych programów penitencjarnych. Dłuższy, niż by się mogło zdawać, „niezbędny” czas pobytu w zakładzie karnym powinien być rozpatrywany, np. pod kątem potrzeby weryfikacji wstępnych (kolejnych) ocen w zakresie możliwości osiągnięcia celów kary.

Ogólnie jednak wypada przyjąć, że możliwości stwarzane przez prawo karne wykonawcze w zakresie modyfikacji kar i środków penalnych w tym postępowaniu są szerokie. Ewolucja prawa w tym względzie zawsze jednak winna podążać w stronę dalszego poszerzania form modyfikacji. Jest to bowiem proces doskonalenia rozwiązań istniejących lub wprowadzania nowych, który zawsze powinien mieć na celu

${ }^{29}$ Ustawa z dnia 5 listopada 2009 r. (Dz.U., Nr 206, poz. 1589). 
pogłębienie efektywności postępowania wykonawczego. Rozumując w podobny sposób, nigdy nie będzie można uznać, że proces ten został zakończony.

Niezależnie od tego, jak dobrze będzie można oceniać rozwiązania normatywne kształtujące teoretyczny (normatywny) model postępowania wykonawczego, nie będzie to miało większego znaczenia w sytuacji, gdy $\mathrm{w}$ praktyce — z różnych zresztą względów — będą stosowane wzorce odbiegające od założonych. W jednej z wypowiedzi do studentów prof. B. Petrykowska wspominała, że w okresie, gdy sprawowała funkcję sędziego wizytatora, dało się odnotować przypadki, kiedy po wejściu w życie w 1965 r. kodeksu cywilnego bywały miejsca, gdzie dalej stosowano kodeks zobowiązań z 1933 r. Odpowiedź na pytanie, dlaczego tak się dzieje, brzmiała: Bo ten nowy się jeszcze „nie przyjął”.

Analizując obecnie orzecznictwo sądów, nader często można odnieść wrażenie, że pomimo długiego już okresu obowiązywania „nowego” prawa karnego nie wszędzie to „nowe” prawo karne także już „się przyjęło”.

Dość skupić się na praktyce orzekania warunkowego zwolnienia. Nie należą do rzadkości przypadki odmowy zastosowania tej instytucji (mówiąc inaczej - modyfikacji zewnętrznej trwałej a warunkowej) z powodów pozaustawowych, np. odległy koniec kary czy rodzaj popełnionego przestępstwa, a nawet wysoki ,stopień społecznego niebezpieczeństwa” popełnionego czynu itd.

Nie można także pomijać, godzących w zasadę humanitaryzmu, poszanowania godności człowieka, orzeczeń sądów meriti, które orzekając karę dożywotniego pozbawienia wolności — w oparciu o art. 77 § 2 k.k. — stosują na tyle drastyczne ograniczenia w dostępie sprawców do zwolnienia warunkowego, że de facto wprowadzona już została do naszego prawa karnego kara pozbawienia wolności bez możliwości zwolnienia warunkowego. Typowym tego przykładem jest casus zabójcy z Łodzi, który skazany w wieku 64 lat ,uzyskał” prawo do ubiegania się o zwolnienie warunkowe po upływie 30 lat kary! O dziesięcioletnim obligatoryjnym okresie próby w takim przypadku (art. $80 § 3$ k.k.) nie wypada chyba wspominać.

Zaznaczmy, że na zasadach ogólnych — zgodnie z art. 78 § k.k. jest to możliwe dopiero po upływie 25 lat. Godzi się dodać, że kodeks 
karny z 1932 r. dopuszczał warunkowe zwolnienie w takim przypadku po 15 latach. Przykłady obostrzeń stosowanych w oparciu o art. 77 § 2 k.k. sięgających 40, 50 lat nie należą do rzadkości w orzecznictwie sądów ${ }^{30}$.

Nie jest to w żadnym razie do pogodzenia już nawet nie tylko z aksjologicznymi motywami polskiego prawa karnego, lecz także (może przede wszystkim) z art. 30 Konstytucji RP, który stanowiąc o potrzebie poszanowania godności człowieka, ma na uwadze również prawo każdego obywatela do nadziei.

Przytaczając fakty, które w ogóle nie powinny mieć miejsca, trzeba pamiętać, że podniesiona kwestia dotyczy innych „drobniejszych” przykładów, których omówienie mogłoby zachwiać strukturą proporcji przedmiotowej wypowiedzi.

Inną barierą, $\mathrm{z}$ jaką w praktyce mamy do czynienia - tym razem w obszarze modyfikacji wewnętrznej — jest przeludnienie zakładów karnych, które wyłącza nie tylko możliwość prawidłowej klasyfikacji skazanych, osadzenia czy zmiany typu, rodzaju zakładu karnego, lecz także efektywne stosowanie środków i metod oddziaływania wychowawczego, takich jak praca, nauka, zajęcia kulturalno-oświatowe itd. ${ }^{31}$ Nie można się zgodzić z potocznym stanowiskiem, przyjmującym brak przeludnienia w sytuacji, gdy liczba osadzonych sięga 90-100\% miejsc w zakładach karnych. Sytuacja taka w praktyce wyklucza na ogół możliwość realizacji zasady indywidualizacji wykonania kary, a w ślad za tym osłabia system wolnej progresji wypełniony treścią programów

30 Zob. np. S. Lelental, Przegląd orzecznictwa Sądu Najwyższego i sądów apelacyjnych $w$ dziedzinie prawa karnego wykonawczego (za lata 1998-1999), „Przegląd Więziennictwa Polskiego" 2000, nr 26, s. 86 n., oraz S. Lelental, Przegląd orzecznictwa Sądu Najwyższego i sądów apelacyjnych $w$ dziedzinie prawa karnego wykonawczego (za lata 2003-2004), „Przegląd Więziennictwa Polskiego” 2005, nr 47-48, s. 63 n.; S. Lelental, Warunkowe przedterminowe zwolnienie w orzecznictwie Sądu Najwyższego i sądów apelacyjnych w latach 1998-2006, „Przegląd Więziennictwa Polskiego” 2007, nr 55, s. 26, w tym zwłaszcza „Przegląd Więziennictwa Polskiego” 2007, nr 49, s. 27-28. G. Wiciński, Glosa do postanowienia Sąu Apelacyjnego w Łodzi z dnia 23 marca 1999, sygn. II AKz 114/99, „Prokuratura i Prawo” 2000, nr 7-8, s. 90 n.; M. Niełaczna, Wykonanie kary dożywotniego pozbawienia wolności w Polsce, „Forum Penitencjarne” 2013, nr 11, s. 16 n.

31 Zob. A. Nawój-Śleszyński, op. cit., s. 147 n.

Nowa Kodyfikacja Prawa Karnego 46, 2017

(C) for this edition by CNS 
wewnętrznej modyfikacji kary pozbawienia wolności, którą kształtują w głównej mierze postępowania autonomiczne ${ }^{32}$.

Jeśli chodzi o orzecznictwo w obszarze środków związanych z poddaniem sprawcy próbie w formie „,prostej ulgi warunkowej”, uważam, że taka praktyka de facto eliminuje możliwości modyfikacji wewnętrznej, a jest to jedną z głównych przyczyn — być może nawet najważniejszą wyjątkowo dużej (co podnoszono) w naszym kraju liczby przypadków, gdy okres próby przebiegł niepomyślnie dla sprawcy ${ }^{33}$. Negatywną ocenę polityki wymiaru kary w tej części wzmacnia niedostatek — racjonalnie rzecz analizując - rzeczowych argumentów dających się doszukać dla jej obrony.

4. Przedstawione zagadnienia mogą skłaniać do stawiania pytań o istnienie bądź brak granic w obszarze modyfikacji kary w postępowaniu wykonawczym.

Wyznaczając relacje brzegowe, w literaturze przedmiotu ${ }^{34}$ - jak podniesiono - przyjmuje się zasadnie, że w stadium wykonawczym nie można skazanego prawomocnie uniewinnić albo uniewinnionego skazać.

Przy założeniu istnienia takich paradygmatów systemowych, jak zasady humanitaryzmu, indywidualizacji, resocjalizacji i potrzeba dążenia do osiągnięcia ustawowych celów kary, należy skupić się na podstawowym - wobec podniesionego problemu — rozróżnieniu modyfikacji na wewnętrzną i zewnętrzną, jako że w tym właśnie obszarze może w największym stopniu ujawniać się polaryzacja ocen.

W pierwszym przypadku dostrzegam głęboką potrzebę elastycznego kształtowania treści kary lub środka penalnego jako sposobu reagowania na postępy w readaptacji społecznej sprawcy albo wobec braku takich postępów czy w obliczu pogłębiania się procesu demoralizacji. Jedynie

32 Zdaniem prof. S. Lelentala o przeludnieniu zakładów karnych należy mówić już wówczas, gdy liczba osadzonych przekracza $80 \%$ miejsc dla osadzonych w jednostkach penitencjarnych w naszym kraju.

33 Zob. T. Szymanowski, Skazania na bezwzględne kary pozbawienia wolności jako następstwo nieefektywnej polityki karnej, „Państwo i Prawo” 2014, nr 4, s. 11.

34 J. Waszczyński, Prawo karne materialne a prawo karne wykonawcze. Problem rozgraniczenia, [w:] Materialy konferencji pt. XX lat Kodeksu karnego wykonawczego i perspektywy dalszego rozwoju prawa karnego wykonawczego, red. S. Lelental, Kalisz 1990, s. 10.

Nowa Kodyfikacja Prawa Karnego 46, 2017

(C) for this edition by CNS 
adekwatne - w takich razach — reakcje organów postępowania wykonawczego mogą prowadzić do osiągnięcia kodeksowych celów kary lub środka penalnego. Mam na uwadze potrzebę większej elastyczności w obszarze zmiany typu, rodzaju zakładu karnego, systemu wykonywania kary pozbawienia wolności, a w przypadku kary ograniczenia wolności albo środków związanych z poddaniem sprawcy próbie - ustanowienie, rozszerzenie, względnie zmianę obowiązków wymienionych w art. $72 \S 1$ k.k. albo oddanie skazanego pod dozór bądź to jego uchylenie itd.

Statyczna postawa właściwych organów postępowania wykonawczego na ogół będzie znacząco utrudniać readaptację społeczną, a w wielu przypadkach uczyni ją wręcz niemożliwą do osiągnięcia; zwłaszcza wówczas, gdy sprawca nie będzie mógł uzyskać niezbędnego wsparcia ze strony instytucji państwa lub organizacji i instytucji pozarządowych. Konsekwencje niepomyślnego przebiegu, np. okresu próby, będące udziałem skazanego, wcale nie muszą w takim wypadku źle o nim świadczyć na tle zagadnienia prognozy kryminologicznej.

W przeszłości problematykę zakresu (granic) modyfikacji zewnętrznej wiązano z kwestią niedopuszczenia do zdeprecjonowania wyroku w postępowaniu wykonawczym. Problem ten pojawił się przede wszystkim w tle nowelizacji kodeksu karnego z 1969 r., która miała miejsce w roku 1985. Dopuszczona została wówczas możliwość warunkowego zwolnienia określonej kategorii osób po odbyciu przez nie co najmniej $1 / 3 \operatorname{kary}^{35}$.

Uważam, że podniesiony problem istnieje również obecnie, jednak postrzegam go w nieco innej optyce. Ryzyko zdeprecjonowania wyroku w postępowaniu wykonawczym nie jest na ogół związane z odniesieniami normatywnymi o charakterze formalnym, lecz przede wszystkim z dążeniem w duchu spójności systemowej do osiągnięcia celów wymiaru kary, o których czytamy w art. $53 \S 1$ k.k. Wydaje się, że w wielu przypadkach nie tylko sądy, ale przede wszystkim ustawodawca tej zależności

35 Dz.U., Nr 23, poz. 100. Zgodnie z art. 91 § 2 d. k.k.: „Warunkowe zwolnienie może nastąpić po odbyciu co najmniej jednej trzeciej kary przez skazanego: 1) za przestępstwo nieumyślne, 2) młodocianego, 3) który sam sprawuje pieczę nad dzieckiem do lat 15, do której wykonania są obowiązani rodzice, 4) będącego kobietą, która w chwili orzekania o warunkowym zwolnieniu ma ukończone 60 lat, albo mężczyzną, który ukończył 65 lat”.

Nowa Kodyfikacja Prawa Karnego 46, 2017

(C) for this edition by CNS 
zdaje się nie doceniać. Tytułem przykładu można skupić się na trzech przypadkach.

Zgodnie z zasadą ultima ratio (art. 58 § 1 k.k.) wymierzenie kary pozbawienia wolności bez warunkowego zawieszenia jej wykonania jest możliwe tylko wtedy, gdy inna kara lub środek karny nie może spełnić celów kary. Wymierzając zatem in concreto karę do roku pozbawienia wolności, sąd - na gruncie art. $53 \S 2$ k.k. - kierował się wyjątkowo poważnymi, a wszechstronnymi argumentami. Tymczasem skazany, już po uprawomocnieniu wyroku, może ubiegać się o wykonywanie kary pozbawienia wolności poza zakładem karnym w systemie dozoru elektronicznego i najpewniej nigdy do więzienia nie trafi.

Podobnie w przypadku popełnienia przestępstwa, za które sąd orzekł karę do roku pozbawienia wolności, z przyczyn niezależnych od sprawcy (przeludnienie zakładów karnych), może on skorzystać z odroczenia jej wykonania (art. $151 \S 2$ k.k.w.), które po roku może sprawić, że w oparciu o art. 152 k.k.w. wykonanie kary zostanie warunkowo zawieszone.

Wreszcie problem zastępczej kary pozbawienia wolności w zamian za nieuiszczoną grzywnę. Zgodnie z art. $46 \S 2$ k.k.w. kara ta nie może przekraczać 12 miesięcy, jak również górnej granicy kary pozbawienia wolności za dane przestępstwo. W przypadku wymierzenia „nieopłacalnie" wysokiej dla sprawcy kary grzywny może on w prosty sposób jej uniknąć. Wystarczy „zdecydować się” na karę zastępczą (np. do roku), którą odbędzie najpewniej w domowych pieleszach z „bransoletką" na nodze (art. 43 lb. k.k.w.).

Ostatnią uwagę dotyczącą kwestii zdeprecjonowania wyroku w postępowaniu wykonawczym o charakterze ogólnym, a dotyczącą stosowania środków związanych z poddaniem sprawcy próbie, wiążę z zagadnieniem prognozy kryminologicznej. Zawsze bowiem, gdy inne niż merytoryczne paradygmaty jej kształtowania mają albo mogą mieć wpływ na decyzję sądu odnośnie do zastosowania programu probacji (np. przeludnienie zakładów karnych, oportunizm, polityka represji), pojawia się realne ryzyko zdeprecjonowania wyroku w postępowaniu wykonawczym.

Już chociażby przedstawione rozważania upoważniają do wniosku uznającego zasadę modyfikacji kary w postępowaniu wykonawczym jako nadrzędną wobec pozostałych w tym rozumieniu, że urzeczywistnia ona w decydującym stopniu zwłaszcza zasadę humanitaryzmu w ujęciu 
dynamicznym, a także indywidualizacji oraz resocjalizacji, które będąc wyrazem sprawiedliwości ekwiwalentnej i naprawczej, otwierają możliwość osiągnięcia finalnego celu kary, jakim jest readaptacja społeczna sprawcy przestępstwa.

\section{The modification process in corrections proceedings}

\section{Summary}

According to the Corrections Code, execution of penalty or penal measure is subject to fulfillment of corrective and preventive goals. Since the 18th century, progressive tendencies regarding imprisonment indicated the need to corrective influence - motivating the perpetrator to exhibit socially-acceptable behavior in order to prevent his relapse into crime. The system of execution of deprivation of liberty (imprisonment) is called a system of slow progression, which means that the penalty can be modified in case of progress in social adaptation or lack of such. The modification process is related to many procedures during execution of penalty. Based on diverse character of such procedures, one can classify them as incidental or autonomous, the latter leading to modification of penalty, e.g. external or internal, permanent, episodic, conditional or unconditional and others, all of which optimize the possibility of fulfillment of the primary goal of the penalty, that is preventing of relapse into crime.

Keywords: Criminal Code, Corrections Code, Penitentiary Court, Constitutional Tribunal, deprivation of liberty, restriction of liberty, fine, probation, penal measures, electronic surveillance system, progressive system of execution of deprivation of liberty, incidental proceedings, autonomous proceedings, modification of penalty, external modification, internal modification, episodic modification, permanent modification, conditional modification, unconditional modification. 